\title{
Early Succession Following Clearcutting of Aspen Communities in Northern Utah
}

\author{
D.L. BARTOS AND W.F. MUEGGLER
}

\begin{abstract}
Changes in aspen reproduction and undergrowth production and composition were recorded over a 3-year period following clearcutting. Aspen suckers increased from 2,300 per hectare prior to cutting to a maximum of $\mathbf{4 4 , 0 0 0}$ per hectare the second post-cut year, and dropped to approximately 25,000 per hectare by the third year. Undergrowth production on the cut units increased from $1,013 \mathrm{~kg} / \mathrm{ha}$ prior to cutting to $3,000 \mathrm{~kg} / \mathrm{ha}$ after three growing seasons; production on the uncut control areas increased from $1,199 \mathrm{~kg} / \mathrm{ha}$ to $1,539 \mathrm{~kg} / \mathrm{ha}$ during this period. The significant increase in undergrowth is attributed to the reduction in competition from the removal of the aspen overstory. Clearcutting appeared to increase the proportion of shrubs in the undergrowth and decrease the proportion of forbs. A similarity index comparing the cut and uncut areas suggested that the greatest change in species composition occurred the first year after cutting, with a gradual return towards the precut conditions.
\end{abstract}

The extensive aspen (Populus tremuloides) forests found at intermediate elevations in the intermountain Rocky Mountain West are highly valued multiple-use lands. They are noted for production of livestock forage, wild life habitat, and scenic beauty, and they are a potentially valuable source of wood products. Through the process of natural plant succession many of these forests are becoming dominated by conifers, frequently within a single aspen generation. Such conversion concerns resource managers because it is usually accompanied by substantial reductions in forage and wildlife habitat. As a consequence, considerable interest has developed in periodically setting back the process of succession in order to maintain communities that are dominated by aspen.

Prescribed burning and clearcutting are the 2 main management alternatives for halting succession to conifers and regenerating the aspen forest. Both of these methods involve drastic disturbance of the plant community. Intelligent use of either requires that we understand not only the effect of such disturbance upon the trees, but upon other components of the community as well.

Burning is a viable alternative for rejuvenating an aspen forest where fuel conditions are amenable to fire and where the trees have little or no commercial value. Recently we published descriptions of early succession following prescribed burning of aspen communities (Bartos and Mueggler 1981). Clearcutting may be desirable either where burning is not feasible or where the value of the wood is sufficient to finance the cutting operation. Although the ability of western aspen to reproduce prolifically following clearcutting is well documented (Jones 1975, Schier 1976, Schier and Smith 1979), very little information is available regarding the changes in undergrowth likely to occur when the tree overstory is removed by clearcutting.

This report describes aspen reproduction and changes in undergrowth composition and production over a 3-year period following

Authors are range scientist and plant ecologist with the Intermountain Forest and Range Experiment Station, USDA Forest Service, located at the Forestry Sciences Laboratory, 860 N. 12 E. Logan, Utah, 84321

The authors wish to thank Dr. William A. Laycock for his help in the initial design of the study and in sampling in 1973. clearcutting aspen communities on the Wasatch National Forest in northern Utah.

\section{Methods}

The Chicken Creek study site is located at an elevation of $2400 \mathrm{~m}$ on the Davis County Experimental Watershed approximately 12.4 $\mathrm{km}$ northeast of Salt Lake City, Utah. The site is dominated by aspen, with a lush understory of forbs and graminoids (Fig. 1) and has not been grazed by domestic livestock for the past 50 years. The main reason for selecting this particular site for cutting was to determine the effects of clearcutting aspen on streamflow rather than to set back conifer invasion. The streamflow information will be reported separately. The site has very deep clayey soils that have good water-holding capacities and the average yearly precipitation is $115 \mathrm{~cm}$ with 80 percent occurring as snow (Johnston and Doty 1972); the overstory tree component was described by Bartos and Johnston (1978). Although conifers were not actively invading the aspen, the cuttings provided an opportunity to study early successional trends following the cutting of aspen-dominated communities.

Eleven and one half hectares of aspen were clearcut in 5 separate blocks in the west branch of Chicken Creek. The study areas occupied northeasterly, northerly, and westerly exposures. The cut blocks were separated by uncut strips of aspen forest, which served as a control in evaluating the effects of cutting on the vegetation. Eighteen permanent $10 \times 10 \mathrm{~m}$ macroplots were established in 1973 prior to cutting. These sample plots, including a $5 \mathrm{~m}$ border, were placed only on areas of uniform vegetation and topog raphy. Nine macroplots were distributed in 4 of the cut blocks and paired with 9 other macroplots with similar vegetation and topography in adjacent uncut areas.

Vegetative production was measured at its peak in early August of 1973, the areas were clearcut in 1974, and the vegetation was

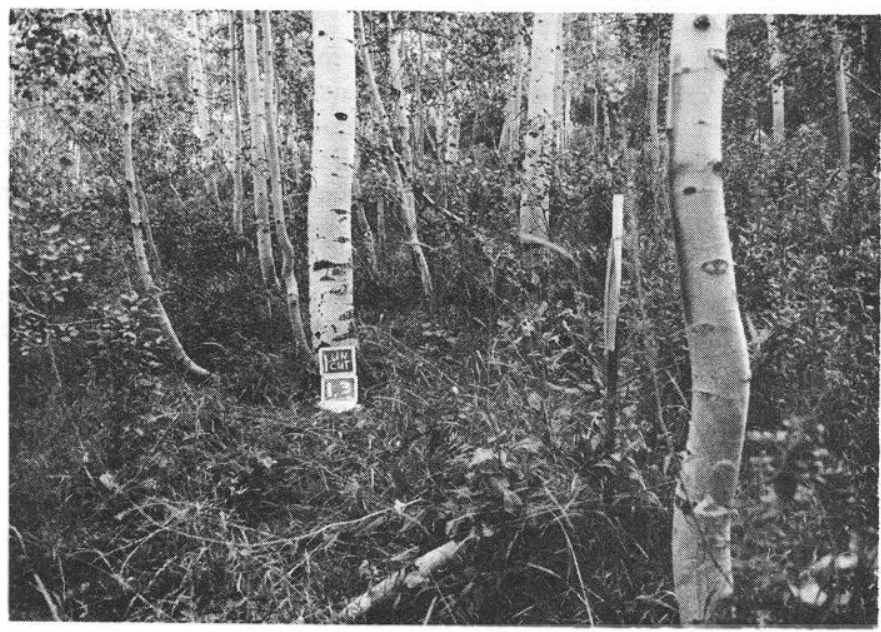

Fig. 1. A general view of the Chicken Creek study site showing a lush undergrowth of forbs and graminoids. 
measured again at its peak in 1975, 1976, and 1977. Production was determined by double-sampling 48 microplots, $30.5 \times 61 \mathrm{~cm}$ in size, systematically distributed within and adjacent to each of the macroplots. Capacitance meter readings (Currie et al. 1973) were obtained on each microplot; 10 of these microplots on each macroplot were then clipped by species to determine percentage composition. Regression equations developed for total production from only those plots both metered and clipped permitted conversion of all meter readings to herbage production. All clipped materials were dried to a constant weight $\left(70^{\circ} \mathrm{C}\right.$ for at least $\left.48 \mathrm{hrs}\right)$. Percentage composition by species was then applied to total production data to yield dry weight by species and vegetation classes.

Permanent subplots each $4 \mathrm{~m}^{2}$ were located within the corners of each macroplot. These subplots were used to count the number of aspen suckers in 1973. In subsequent years, sucker numbers were counted on the entire $100 \mathrm{~m}^{2}$ macroplots to obtain greater accuracy.

The cutting operation was carried out during the 1974 growing season. All trees over $5.1 \mathrm{~cm} \mathrm{d.b.h.} \mathrm{were} \mathrm{cut} \mathrm{(approximately} \mathrm{15,000}$ $\mathrm{m}^{3} / \mathrm{ha}$ ) and all usable boles were removed from the site for firewood. To minimize site disturbances, horses were used to skid the boles and the slash was left in place. (Slash was removed from the macroplots and adjacent border to facilitate sampling.) Data from the 4 cutting units were combined even though the units represented different exposures. This was done because (1) vegetation on the units did not differ greatly, (2) response of the vegetation to cutting was generally similar, and (3) the limited number of paired macroplots did not permit a legitimate statistical analysis of differences between units.

A paired $t$-test was used to evaluate the differences in undergrowth production between the cut and uncut areas. A paired $t$-test using 1973 as the base year was also used to determine the signifi-
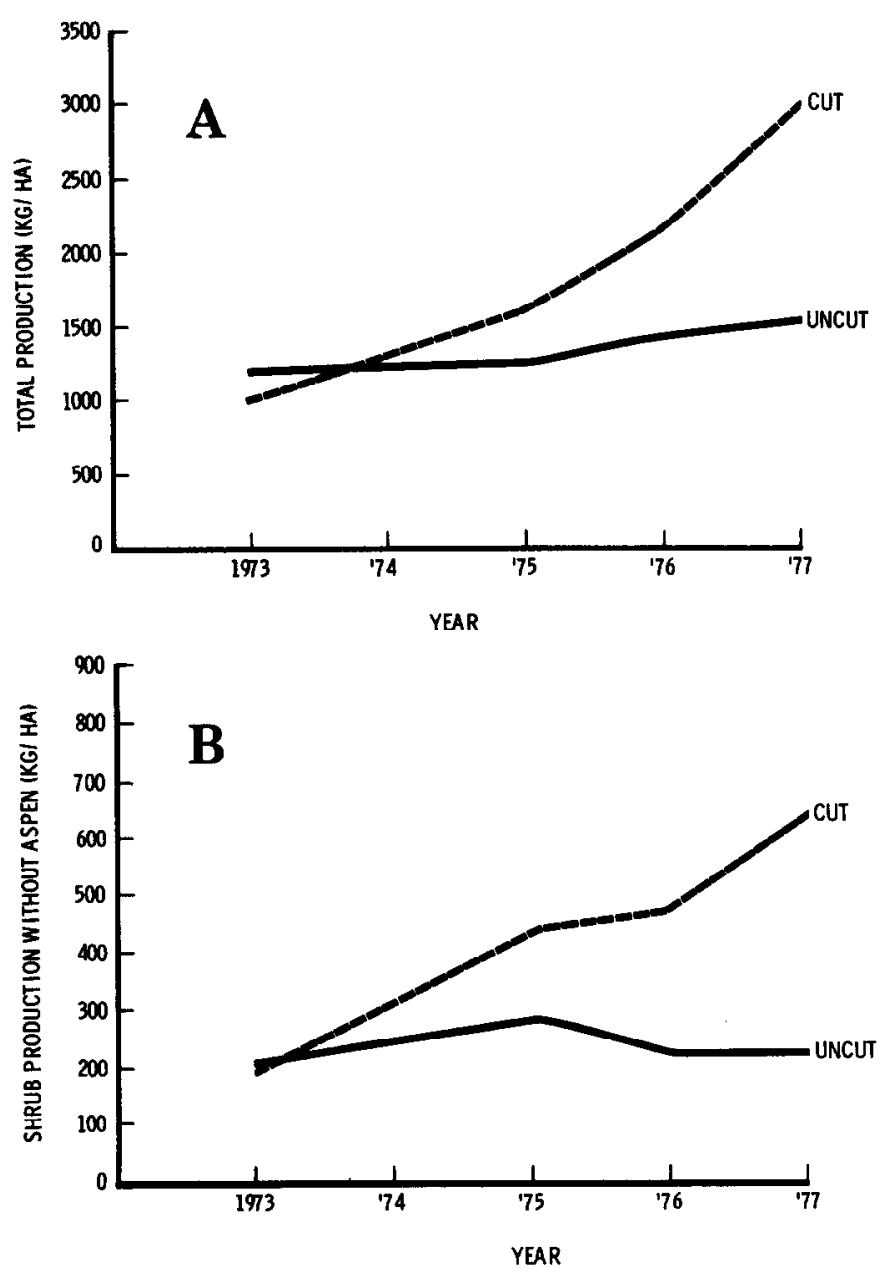

cance of production changes on the uncut areas which are attributable to weather.

\section{Results and Discussion}

\section{Undergrowth Production}

In 1973, before cutting, total production of undergrowth on the areas to be clearcut and on those to be left as controls did not differ significantly (Table 1). Although production on the uncut control increased slightly over the study period, until it was $28 \%$ greater in
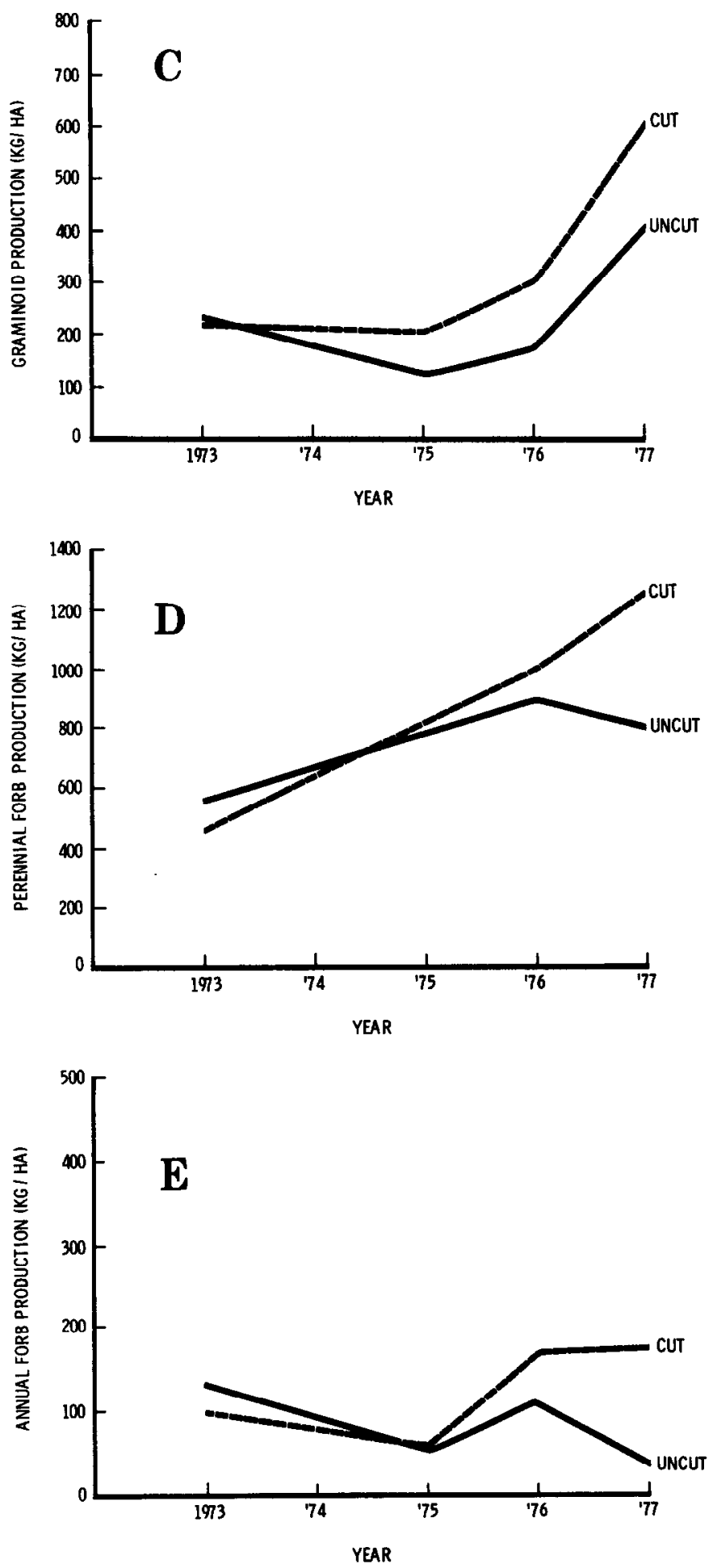

Fig. 2. Changes in production (dry $\mathrm{kg} / \mathrm{ha}$ ) of undergrowth on clearcut aspen and uncut control areas in 1973 before cutting in 1974, and during the first 3 years following cutting. 
Table 1. Total dry weight production $(\mathrm{kg} / \mathrm{ha})$ and standard error on clearcut aspen and on uncut control areas in 1973 before cutting in 1974, and during the first 3 years following cutting.

\begin{tabular}{|c|c|c|c|c|c|c|c|c|}
\hline & \multicolumn{2}{|c|}{1973} & \multicolumn{2}{|c|}{1975} & \multicolumn{2}{|c|}{1976} & \multicolumn{2}{|c|}{1977} \\
\hline & Cut & Uncut & $\mathrm{Cut}$ & $\overline{\text { Uncut }}$ & Cut & $\overline{\text { Uncut }}$ & Cut & Uncut \\
\hline Total & 1013 & 1199 & 1625 & 1267 & 2175 & 1431 & 3002 & 1539 \\
\hline Standard error & 61 & 86 & 118 & 126 & 154 & 96 & 129 & 86 \\
\hline
\end{tabular}

1977 than in 1973, undergrowth production on the cut areas trebled (Fig. 2A). The small but statistically significant increase in production on the uncut areas was probably the result of natural variations in weather, but this could not be verified. The very great increase in production on the cut areas is probably a combination of the effects of weather and release from competition caused by clearcutting. In each of the 3 years following cutting, production of undergrowth was significantly greater on the cut than on the uncut control. By the third post-cut year, the clearcuts were producing twice as much total shrubs, forbs, and graminoids as the uncut aspen forest.

Perennial forbs contributed considerably more to the total undergrowth production (approximately 50\%) both before and after clearcutting than any other vegetation class (Fig. 2). Forb production on the uncut areas varied but increased about one-third over the study period, presumably because of weather differences. Significantly less forbs occurred on the cut areas than on the uncut areas before cutting in 1973. Clearcutting the aspen, however, caused a rapid and progressive increase in production of forbs. By the third post-cut year, forb production had more than doubled on the cut areas, and was more than $50 \%$ greater than that on the uncut control (Fig. 2D).

Grasses and sedges comprised about $20 \%$ of the original undergrowth production. These graminoids were equally abundant on the cut and uncut area sinitially. They increased appreciably during the study period on both treatments (Fig 2C). Although the increase was greatest on the cut areas, differences in production between the cut and the uncut were statistically significant only in 1975 because of the variability in production among macroplots.

Shrubs, excluding aspen reproduction, made up slightly less than $20 \%$ of the undergrowth production, and were equally abundant on the cut and uncut areas initially. (Our production values for shrubs consist only of the current growth of twigs, leaves, and fruits). Shrub production did not change appreciably on the control areas during the study period. On the cut areas, however, shrub production doubled the first post-cut year, and by the third year

Table 2. Undergrowth composition (\%) on clearcut aspen and uncut control areas in 1973 before cutting in 1974 , and in the first 3 years following cutting.

\begin{tabular}{|c|c|c|c|c|c|c|c|c|}
\hline \multirow[b]{2}{*}{ Species } & \multicolumn{2}{|c|}{1973} & \multicolumn{2}{|c|}{1975} & \multicolumn{2}{|c|}{1976} & \multicolumn{2}{|c|}{1977} \\
\hline & Cut & Uncut & Cut & Uncut & Cut & Uncut & Cut & Uncut \\
\hline $\begin{array}{l}\text { Shrubs: } \\
\text { Populus tremuloides } \\
\text { Prunus virginiana } \\
\text { Rosa ssp. } \\
\text { Sambucus spp. } \\
\text { Symphoricarpos oreophyllus } \\
\text { Total shrubs }\end{array}$ & $\begin{array}{r}0.5 \\
3.7 \\
-0- \\
0.1 \\
15.4 \\
19.7\end{array}$ & $\begin{array}{r}0.1 \\
0.9 \\
-0- \\
0.3 \\
15.8 \\
17.1\end{array}$ & $\begin{array}{r}5.1 \\
10.8 \\
1.0 \\
-0- \\
14.9 \\
31.8\end{array}$ & $\begin{array}{r}0.5 \\
1.7 \\
1.1 \\
2.7 \\
16.5 \\
22.5\end{array}$ & $\begin{array}{r}10.8 \\
6.9 \\
-0- \\
-0- \\
14.7 \\
32.4\end{array}$ & $\begin{array}{r}1.1 \\
2.2 \\
0.4 \\
1.0 \\
11.9 \\
16.6\end{array}$ & $\begin{array}{c}8.6 \\
8.8 \\
0.1 \\
- \\
12.3 \\
29.8\end{array}$ & $\begin{array}{c}2.8 \\
1.3 \\
-0- \\
- \\
12.8 \\
16.9\end{array}$ \\
\hline $\begin{array}{l}\text { Graminoids: } \\
\text { Agropyron trachycaulum } \\
\text { Bromus carinatus } \\
\text { Carex hoodii } \\
\text { Elymus glaucus } \\
\text { Poa cusickii } \\
\text { Total graminoids }\end{array}$ & $\begin{array}{r}3.6 \\
11.6 \\
-0- \\
4.8 \\
1.8 \\
21.8\end{array}$ & $\begin{array}{r}2.9 \\
9.3 \\
2.2 \\
3.9 \\
0.8 \\
19.1\end{array}$ & $\begin{array}{r}3.4 \\
6.5 \\
0.1 \\
2.5 \\
0.1 \\
12.6\end{array}$ & $\begin{array}{l}2.1 \\
4.8 \\
1.2 \\
1.4 \\
0.2 \\
9.7\end{array}$ & $\begin{array}{r}2.6 \\
10.5 \\
0.4 \\
0.5 \\
-0- \\
14.0\end{array}$ & $\begin{array}{r}3.2 \\
4.3 \\
3.6 \\
0.5 \\
0.3 \\
11.9\end{array}$ & $\begin{array}{c}8.4 \\
9.1 \\
0.1 \\
2.6 \\
- \\
20.2\end{array}$ & $\begin{array}{r}3.8 \\
15.7 \\
1.8 \\
4.7 \\
\overline{26.0}\end{array}$ \\
\hline $\begin{array}{l}\text { Perennial forbs: } \\
\text { Agastache urticifolia } \\
\text { Aster engelmannii } \\
\text { Chlorocrambe hastatus } \\
\text { Erigeron spp. } \\
\text { Hackelia floribunda } \\
\text { Heracleum lanatum } \\
\text { Lathyrus leucanthus } \\
\text { Mertensia arizonica } \\
\text { Osmorhiza chilensis } \\
\text { Osmorhiza occidentalis } \\
\text { Rudbeckia occidentalis } \\
\text { Scrophularia lanceolata } \\
\text { Senecio serra } \\
\text { Stellaria jamesiana } \\
\text { Thalictrum fendleri } \\
\text { Valeriana occidentalis } \\
\text { Vicia americana } \\
\text { Total perennial forbs }\end{array}$ & $\begin{array}{r}4.9 \\
2.5 \\
\overline{1} .0 \\
0.9 \\
-0- \\
3.3 \\
0.8 \\
1.4 \\
-0- \\
3.8 \\
0.1 \\
4.3 \\
3.1 \\
0.7 \\
17.9 \\
0.8 \\
45.5\end{array}$ & $\begin{array}{r}3.5 \\
1.3 \\
0.7 \\
0.7 \\
1.5 \\
3.9 \\
6.6 \\
0.4 \\
1.0 \\
0.5 \\
1.9 \\
3.4 \\
2.7 \\
1.3 \\
14.9 \\
0.3 \\
46.8\end{array}$ & $\begin{array}{r}5.4 \\
2.3 \\
-0- \\
1.0 \\
0.9 \\
1.8 \\
2.2 \\
0.2 \\
0.5 \\
0.3 \\
3.6 \\
4.7 \\
10.1 \\
2.7 \\
1.0 \\
11.0 \\
2.5 \\
50.2\end{array}$ & $\begin{array}{r}3.6 \\
1.1 \\
1.0 \\
-0- \\
3.8 \\
-0- \\
3.9 \\
4.1 \\
0.3 \\
2.1 \\
8.5 \\
7.6 \\
4.7 \\
3.1 \\
0.1 \\
17.0 \\
0.8 \\
61.7\end{array}$ & $\begin{array}{r}6.1 \\
1.1 \\
0.1 \\
1.3 \\
1.7 \\
0.7 \\
1.7 \\
1.1 \\
-0- \\
0.3 \\
6.0 \\
4.5 \\
6.9 \\
1.7 \\
0.1 \\
11.2 \\
1.1 \\
45.6\end{array}$ & $\begin{array}{r}9.6 \\
0.7 \\
0.4 \\
-0- \\
1.2 \\
0.3 \\
2.9 \\
8.1 \\
1.5 \\
0.7 \\
6.1 \\
2.8 \\
9.9 \\
2.6 \\
0.2 \\
12.8 \\
2.2 \\
62.0\end{array}$ & $\begin{array}{r}5.3 \\
3.9 \\
0.2 \\
1.6 \\
0.3 \\
0.4 \\
2.6 \\
0.5 \\
0.1 \\
0.7 \\
7.3 \\
6.0 \\
4.2 \\
0.8 \\
0.2 \\
6.7 \\
0.7 \\
41.5\end{array}$ & $\begin{array}{r}5.0 \\
2.7 \\
1.5 \\
0.3 \\
0.3 \\
0.4 \\
5.1 \\
5.1 \\
-0- \\
0.9 \\
7.1 \\
6.5 \\
6.7 \\
0.6 \\
0.7 \\
8.4 \\
0.8 \\
52.1\end{array}$ \\
\hline $\begin{array}{l}\text { Annual forbs: } \\
\text { Chenopodium album } \\
\text { Collomia linearis } \\
\text { Galium bifolium } \\
\text { Nemophila breviflora } \\
\text { Polygonum douglasil } \\
\text { Total annual forbs }\end{array}$ & $\begin{array}{l}0.4 \\
0.9 \\
2.3 \\
3.4 \\
2.6 \\
9.6\end{array}$ & $\begin{array}{r}0.3 \\
0.8 \\
2.8 \\
4.3 \\
2.4 \\
10.6\end{array}$ & $\begin{array}{l}0.3 \\
0.2 \\
1.0 \\
1.1 \\
0.7 \\
3.3\end{array}$ & $\begin{array}{l}0.2 \\
0.5 \\
0.7 \\
1.9 \\
0.7 \\
4.0\end{array}$ & $\begin{array}{l}1.5 \\
1.6 \\
0.3 \\
0.2 \\
4.1 \\
7.7\end{array}$ & $\begin{array}{l}1.1 \\
1.8 \\
0.2 \\
1.8 \\
2.7 \\
7.6\end{array}$ & $\begin{array}{l}0.5 \\
0.1 \\
-0- \\
- \\
5.2 \\
5.8\end{array}$ & $\begin{array}{l}0.5 \\
0.2 \\
-0- \\
- \\
1.6 \\
2.3\end{array}$ \\
\hline Other species & 3.4 & 6.4 & 2.1 & 2.1 . & 0.3 & 1.9 & 2.7 & 2.7 \\
\hline
\end{tabular}

IOnly reproduction under $2 \mathrm{~m}$ tall and $<5.1 \mathrm{~cm} \mathrm{d.b.h.}$ 
was 3 times what it was before cutting (Fig 2B). The increase over the uncut was statistically significant by the third year.

Annuals, consisting exclusively of forbs, initially formed approximately $10 \%$ of the undergrowth. Annuals are particularly subject to the vagaries of weather and competitive influences, as evidenced by their erratic production trends over the study period (Fig. 2E). In contrast to the behavior of the other vegetation classes, annuals decreased on the cut as well as on the uncut area the first year after cutting. They then increased significantly on the cut area, so that by the third year production of annuals was fivefold that on the uncut areas. The decrease in annuals immediately following cutting and subsequent increase was unexpected. We assumed that annuals, being opportunistic, would increase appreciably the first year with the immediate reduction in competition and then decrease somewhat as the perennials increased. The initial decrease on both the cut and uncut areas may simply indicate that the weather in 1975 was unfavorable for growth of annuals, and this completely negated the effect of reduced competition. This lack of annual production could be attributed in part to a heavy snowpack during 1974-75, which remained until late June.

Thus, early succession following clearcutting of aspen communities is characterized by a significant increase in the amount of all undergrowth vegetation. This increase is attributed to the reduction in competition from an aspen overstory. As succession proceeds and aspen regains dominance, we expect the upward trend in production of forbs, graminoids, and shrubs to level off and then
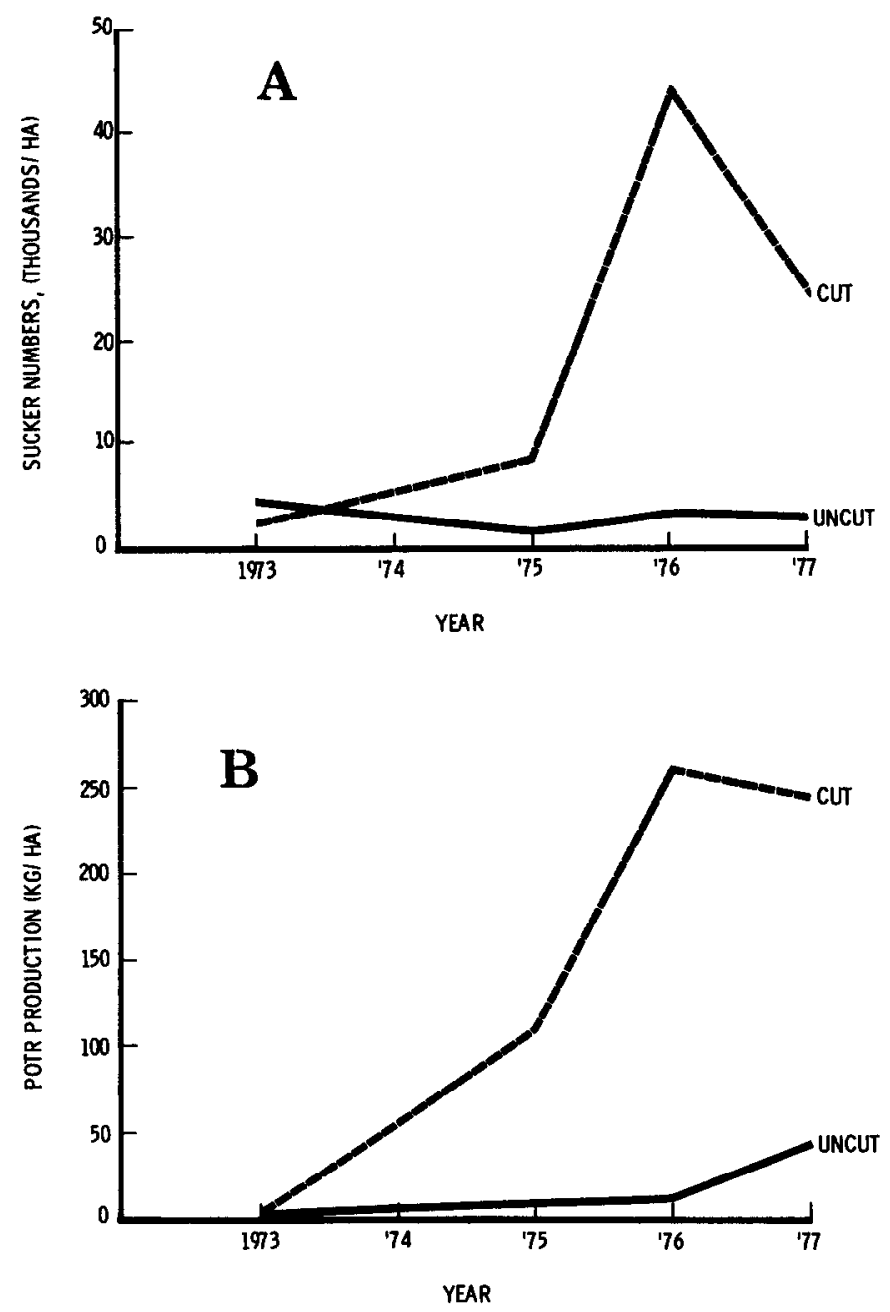

Fig. 3. Changes in the number ( $A$ ) and dry weight (B) of aspen suckers on clearcut and uncut control areas in 1973 before cutting in 1974, and during the first 3 years following cutting. gradually decrease. Aspen suckers grow rapidly following clearcutting and may begin to suppress production of undergrowth within a relatively few years.

\section{Species Composition}

Composition of the undergrowth in these aspen forests was fairly complex. Thirty-two species of plants were sufficiently abundant to individually constitute at least $1 \%$ of the undergrowth production in any one year on either of the treatment areas (Table 2).

In general, clearcutting appeared to increase the proportion of shrubs in the undergrowth and decrease the proportion of forbs. In other words, the relative amount of shrubs as a class increased more than the forbs as a class. Even though graminoid production increased on the cut area, its proportion of the total undergrowth did not change appreciably because of cutting.

Forbs contributed most to undergrowth composition in both quantity and in numbers of species. The most abundant forbs were western valerian (Valeriana occidentalis), butterweed groundsel (Senecio serra), nettleleaf giant hyssop (Agastache urticifolia), lanceleaf figwort (Scrophularia lanceolata), and western coneflower (Rudbeckia occidentalis). The relative proportion of different forb species changed from year to year on both the cut and uncut areas (Table 2.) Few species of forbs appeared to be disproportionately favored or harmed by the environmental changes caused by clearcutting. Douglas knotweed (Polygonum douglasii), an annual, appeared to increase proportionately more than any of the other forbs. Butterweed groundsel may have been unusually benefited the first post-cut year, but its increase did not persist. Western valerian was the only forb that appeared to decrease because of clearcutting.

The proportion of graminoids in the undergrowth varied considerably over the study period, from a low of about $10 \%$ of the total understory to a high of more than $25 \%$ (Table 2). Mountain brome (Bromus carinatus), slender wheatgrass (Agropyron trachycaulum), and blue wildrye (Elymus glaucus) were most abundant. Slender wheatgrass was the only species that appeared to be disproportionately affected by clearcutting; its percent composition increased from about $3 \%$ of the total undergrowth to $8 \%$.

During the study period, production of shrubs remained fairly constant on the control areas: 16 to $22 \%$ of the total undergrowth. Mountain snowberry (Symphoricarpos oreophyllus) and common chokeberry (Prunus virginiana) were by far the most abundant shrubs. The proportion of mountain snowberry in the community did not appear to be affected by clearcutting. The proportion of common chokecherry, however, appeared to increase on the clearcut areas.

To facilitate understanding the overall divergence of undergrowth composition caused by clearcutting, we computed Sorensen's community coefficient (Mueller-Domboise and Ellenberg 1974) as an index to the similarity of the cut and uncut areas each year. The data used in this comparison were percentage composition of the undergrowth species rather than actual quantities. Aspen overstory was excluded from the analysis. The index thus compares proportions of species irrespective of differences in total undergrowth production. An index value of 1.00 indicates identical matching of species and composition on the compared areas; a value of 0.00 indicates that the areas have no species in common.

The similarity index between combined macroplots on the cut areas and combined macroplots on the uncut areas was 0.78 before clearcutting in 1973. This value suggests reasonably good agreement in the relative amounts of species in the 2 treatment categories. The index dropped to 0.66 the first post-cut year and then increased to 0.70 the second year and to 0.73 the third year. This suggests that the greatest overall change in species composition on the clearcut areas occurred the first year following cutting, and that recovery of the balance between undergrowth species began soon after even though total productivity of undergrowth continued to increase into the third year. 


\section{Aspen Suckers}

The number of aspen suckers remained fairly constant on the uncut areas throughout the study period, varying from approximately 1,400 to 4,300 per hectare (Fig. 3A). These suckers remained small and contributed little to the total current-year's production of undergrowth (Fig 3B). As expected, clearcutting the aspen overstory stimulated profuse suckering of aspen, particularly the second growing season following cutting. Sucker numbers increased from 2,300 per hectare before cutting, to 8,500 the first post-cut year, and to a maximum of 44,000 the second post-cut year. By the second year, current twig and leaf production of aspen suckers on the cut areas comprised over $10 \%$ of the total production of undergrowth. Numbers of suckers dropped the third postcut year to approximately 25,000 per hectare, but production of twigs and leaves decreased only slightly.

The 20-fold increase in sucker production is similar to what we reported for an aspen clearcut in southern Utah (Mueggler and Bartos 1977). Smith and others (1972) reported 74,000 to 124,000 suckers per hectare after clearcutting aspen in northern Utah, Jones (1975) found 35,000 suckers per hectare on aspen clearcuts in Arizona and in southwestern Colorado 15,000 to 25,000 suckers per hectare was reported by Hittenrauch (1976). Jones (1976) indicated that 50,000 to 75,000 suckers per hectare is not excessive because of the natural thinning that occurs in aspen stands. A mature stand of aspen in this site contains from 700 to 3,600 stems per hectare.

\section{Literature Cited}

Bartos, D.L., and R.S. Johnston. 1978. Biomass and nutrient content of quaking aspen at two sites in the western United States. Forest Sci. 24(2):278-280.

Bartos, D.L., and W.F. Mueggler. 1981. Early succession in aspen communities following fire in western Wyoming. J. Range Manage. 34:315318.

Currie, P.0., M.J. Morris, and D.L. Neal. 1973. Uses and capabilities of electronic capacitance instruments for estimating standing herbage. Part 2. Sown Ranges. J. Br. Grassl. Soc. 28:155-160.

Hittenrauch, H.R. 1976. Response of aspen to various harvest techniques. In: Utilization and Marketing as Tools for Aspen Management in the Rocky Mountains. USDA, FS Gen. Tech. Rep. RM-29:41-44.

Jones, J.R. 1975. Regeneration on an aspen clearcut in Arizona. USDA, FS Res. Note RM-285. 8 p.

Jones, J.R. 1976. Aspen harvesting and reproduction. In: Utilization and Marketing as Tools of Aspen Management in the Rocky Mountains. USDA, FS Gen. Tech. Rep. RM-29:30-34.

Johnston, R.S., and R.D. Doty. 1972. Description and hydrologic analysis of two small watersheds in Utah's Wasatch Mountains. USDA FS. Res. Pap. INT-127. 53 p.

Mueggler, W.F., and D.L. Bartos. 1977. Grindstone Flat and Big Flat exclosures-a 41-year record of changes in clearcut aspen communities. USDA, FS Res. Pap. INT-195. 16 p.

Mueller-Domboise, D., and H. Ellenberg. 1974. Aims and Methods of Vegetation Ecology. John Wiley and Sons, New York. 547 p.

Schier, G.A. 1976. Physiological and environmental factors controlling vegetative regeneration in aspen. In: Utilization and Marketing as Tools for Aspen Management in the Rocky Mountains. USDA FS Gen. Tech. Rep. RM-29-20-23.

Schier, G.A., and A.D. Smith. 1979. Sucker regeneration in a Utah aspen clone after clearcutting, partial cutting, scarification, and girdling. USDA FS Res. Note INT-253. 6 p.

Smith, A.D., P.A. Lucas, C.E. Baker, and G.W. Scotter. 1972. The effects of deer and livestock on aspen regeneration in Utah. Utah Division of Wildlife Resources, Pub. 72-1. 32 p.

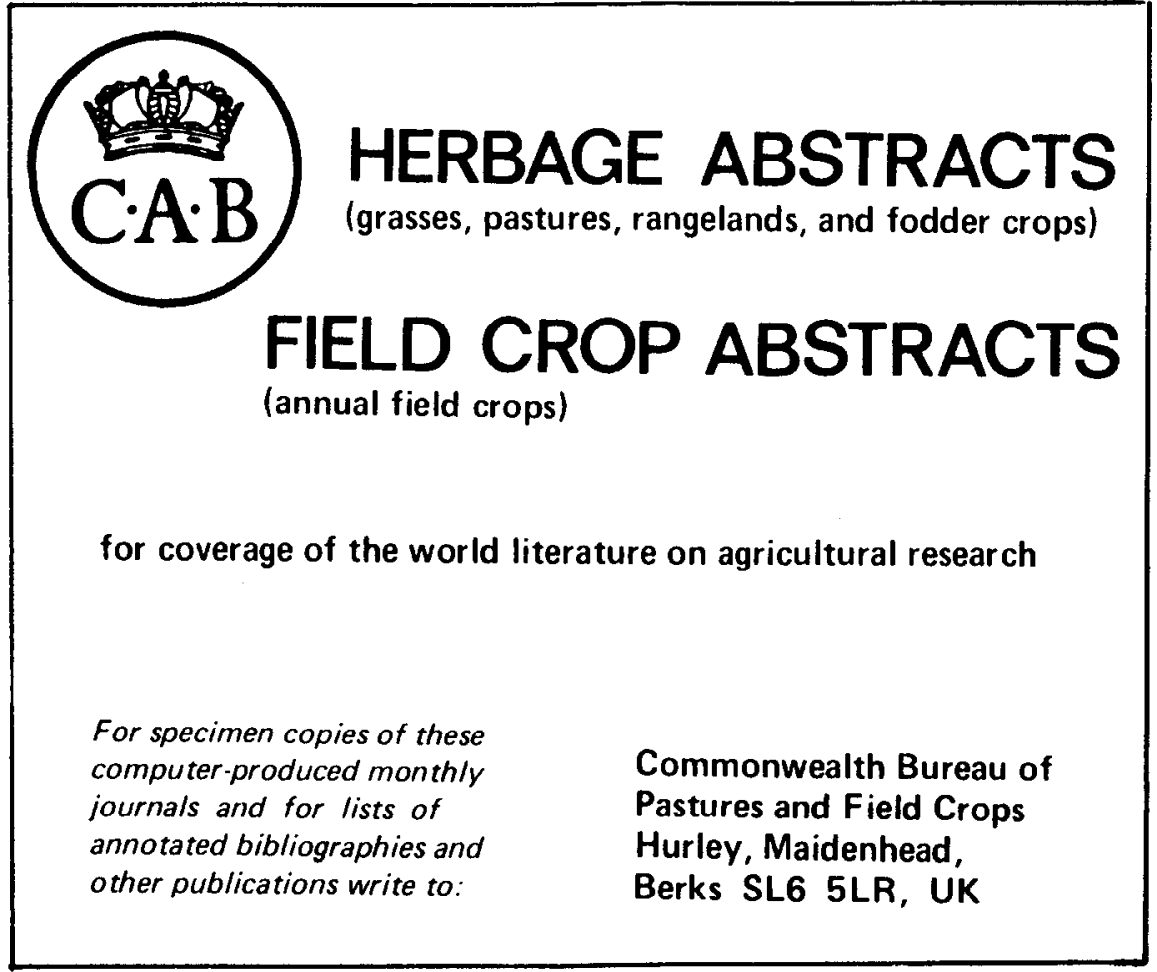

